\title{
Divergence time estimations and contrasting patterns of genetic diversity between Antarctic and southern South America benthic invertebrates
}

\author{
Estimaciones de los tiempos de divergencia y patrones contrastantes de diversidad \\ genética entre invertebrados bentónicos de Antártica y el extremo austral de Sudamérica
}

\author{
CLAUDIO ALEJANDRO GONZÁLEZ-WEVAR ${ }^{1, ~}{ }^{*}$, ANGIE DÍAZ ${ }^{1}$, KARIN GERARD ${ }^{1}$, JUAN IVÁN CAÑETE ${ }^{2}$ \\ \& ELIE POULIN ${ }^{1}$
}

${ }^{1}$ Laboratorio de Ecología Molecular, Instituto de Ecología y Biodiversidad (IEB), Departamento de Ciencias Ecológicas, Facultad de Ciencias, Universidad de Chile, Las Palmeras 3425, Nuñoa, Santiago, Chile

2Departamento de Recursos Naturales, Universidad de Magallanes, Av. Bulnes 01890, Casilla 113-D, Punta Arenas, Chile

${ }^{*}$ Corresponding author: omeuno01@hotmail.com

\begin{abstract}
Diversity, abundance and composition of taxonomic groups in the Southern Ocean differ from elsewhere in the planet, since the biogeography in this region reflects the complex interactions of tectonics, oceanography, climate and biological elements since the Eocene. Several groups of marine benthic organisms exhibit high levels of genetic divergence among provinces in this region, supporting the existence of a vicariance process through plate tectonics, while other groups with high dispersive capacity exhibit recent divergence processes. Moreover, the discovery of nonAntarctic decapod larvae in Antarctic Peninsula suggests that some groups can travel across the Antarctic Circumpolar Current. Here we analyzed levels of genetic divergence in congeneric species of three Southern Ocean's benthic invertebrate groups with dispersive potential. For this purpose we included in the analyses COI sequences of an echinoid (Sterechinus), a gastropod (Nacella), and a bivalve (Yoldia). Considering the levels of genetic differentiation and assuming the molecular clock hypothesis we estimated the separation of invertebrates from the two continents. We also compared levels of genetic variation between Antarctic and sub-Antarctic species of Nacella and Sterechinus to determine the effect of the Quaternary glacial episodes in the demography of these species. We detected clear genetic differences between Antarctic and sub-Antarctic congeneric species of Sterechinus, Nacella, and Yoldia. According to our results, the installation of an effective barrier between Antarctica and sub-Antarctica occurred almost at the same time (between 3.7 and $5.0 \mathrm{Ma}$ ) for these groups of organisms, long after the physical separation of both continents. Genetic comparisons between Antarctic and Sub-Antarctic species of Nacella and Sterechinus detected lower levels of genetic diversity in Antarctic species, suggesting more pronounced effects of the glacial episodes in Antarctica than in South America. These results may reflect the dramatic effect of the Quaternary glacial cycles on Antarctic population sizes, especially in groups with narrow bathymetric ranges. The present study provides new evidence about the differentiation processes between Antarctic and South American organisms. None of the analyzed genera showed evidence for recurrent gene flow across the Antarctic Circumpolar Current since the Mio-Pliocene. Genetic comparisons indicate that Antarctic and Sub-Antarctic species were differentially affected by glacial periods.
\end{abstract}

Key words: Antarctic Circumpolar Current, COI, oceanographic barrier, planktotrophy, Pliocene separation.

\section{RESUMEN}

La diversidad, abundancia y composición de grupos taxonómicos en el océano Austral difiere de otros lugares del planeta debido a que su biogeografía refleja la compleja interacción de la tectónica, oceanografía, clima y elementos biológicos desde el Eoceno. Algunos grupos de organismos marinos bentónicos muestran altos niveles de divergencia genética entre provincias de esta región, apoyando la existencia de procesos vicariantes por tectónica de placas mientras que otros grupos, con alta capacidad dispersiva, muestran procesos de divergencia más recientes. Más aún, el reciente descubrimiento de larvas de decápodos no Antárticos en península Antártica sugiere que algunos grupos podrían cruzar la Corriente Circumpolar Antártica. Se analizaron los niveles de divergencia genética en especies congenéricas en invertebrados bentónicos del Océano Austral con potencial dispersivo. Para esto, se incluyó en los análisis secuencias del gen COI de un equinoídeo (Sterechinus), un gastrópodo (Nacella), y un bivalvo (Yoldia). Considerando los niveles de diferenciación genética y asumiendo la Hipótesis del Reloj Molecular, estimamos la separación entre grupos de ambos continentes. También comparamos los niveles de variación genética entre especies antárticas y subantárticas de Nacella y Sterechinus para determinar el efecto de los episodios glaciales del Cuaternario en su demografía. Detectamos claras diferencias genéticas entre especies congenéricas antárticas y subantárticas de Sterechinus, Nacella y Yoldia. La instalación de una barrera efectiva entre antártica y subantártica ocurrió casi al unísono (3.7 a $5.0 \mathrm{Ma}$ ) para estos grupos de organismos, y muy posterior a la separación física de ambos continentes. Comparaciones genéticas entre especies antárticas y subantárticas detectaron menores niveles de diversidad 
genética en especies antárticas sugiriendo un efecto más pronunciado de los episodios glaciales en Antártica que en Sudamérica. Estos resultados podrían reflejar el dramático efecto de los ciclos glaciales del Cuaternario en los tamaños poblacionales antárticos, especialmente en grupos con rangos batimétricos estrechos. El presente estudio provee nueva evidencia de los procesos de diferenciación entre organismos antárticos y sudamericanos. Ninguno de los géneros analizados mostró evidencia de flujo génico recurrente a través de la Corriente Circumpolar Antártica desde el Mio-Plioceno. Las comparaciones genéticas indican que especies antárticas y subantárticas fueron diferencialmente afectadas por los periodos glaciales.

Palabras clave: barrera oceanográfica, COI, Corriente Circumpolar Antártica, planctotrofía, separación en el Plioceno.

\section{INTRODUCTION}

The Southern Ocean (SO) includes all waters south of the Polar Front, a well-defined circumAntarctic oceanographic area that marks the northernmost extent of cold surface water (Rintoul et al. 2001, Aronson et al. 2008). Its total area is about 35 million $\mathrm{km}^{2}$, of which more than $60 \%$ is covered by ice during the winter maximum and $20 \%$ is covered during the summer minimum (Zwally et al. 2002). Since the Mesozoic this region has undergone major tectonic, oceanographic and climatic changes that operated at different temporal and spatial scales (Knox 1980, Clarke \& Crame 1989, 1992, Zachos et al. 2001, Griffiths et al. 2009). The geological history of the SO is deeply connected to the fragmentation and the dispersion of the continental blocks that formed the supercontinent Gondwana and to the opening of gateways between Antarctica, Australia and South America (Lawver et al. 1993, Barker \& Thomas 2004, Pfühl \& McCave 2005, Scher \& Martin 2006, Torsvik et al. 2008). Reconstructions of paleo-currents of the past 55 Ma have shown that the opening of the Tasman gateway and the Drake Passage shaped past and present oceanographic circulation of the SO (Kennett 1980, Knox 1980, 2007, Woodruff et al. 1989, Stickley et al. 2004, Livermore et al. 2005). The formation of these gateways influenced the initiation of the Antarctic Circumpolar Current (ACC), the major current system transporting more than $130 \mathrm{~Sv}$ ( $1 \mathrm{~Sv}$ $=10^{6} \mathrm{~m}^{3} \mathrm{seg}^{-1}$ ) through the Drake Passage (Orsi et al. 1995). This current flows around Antarctica and is delimited by the Polar and the sub-Antarctic fronts (Barker et al. 2007). Mackensen (2004) recognized three main periods in which major changes affected the circulation of the ACC and the climate of the SO: (1) the Ecocene/Oligocene boundary when the origin of the ACC significantly modified global oceanic circulation. (2) The middle Miocene $(\sim 14 \mathrm{Ma})$ when the re-establishment of an East Antarctic ice sheet influenced mode and levels of Antarctic bottom water formation, generating an intensification of the ACC. (3) The Quaternary, characterized by the alternation between glacial and interglacial periods. It is likely that the intensity of the ACC has varied in response to processes related to Quaternary glacial cycles (Gersonde et al. 2005, Hassold et al. 2009). In the South Atlantic, Indian and South Pacific Oceans, the whole current system can migrate north or south by several degrees of latitude as a response to a change in volume transport (Pudsey \& Howe 1998). The positions of the ACC fronts (Polar and Sub-Antarctic) have important implications for the biogeography of the region, they act as a gene flow barrier for some species (Shaw et al. 2004, González-Wevar et al. 2010), while for others they constitute important transportation vectors (Beu et al. 1997, Page \& Linse 2002, Thorpe et al. 2004, Waters 2008, Fraser et al. 2009, Díaz et al. 2011).

The distribution, abundance and composition of the marine near-shore fauna in the SO reflect complex interactions of geological, oceanographic and biological factors through space and time (Knox 1980, Lawver et al. 1993, Clarke \& Johnston 1996, Crame 1999, Zachos et al. 2001, Linse et al. 2006, Rogers 2007, Knox 2007, Aronson et al. 2008, Griffiths et al. 2009). Continental drift and extreme climatic changes that have characterized the Antarctic continent since the Mesozoic deeply impacted the SO marine near-shore biota (Clarke \& Crame 1989, Clarke \& Johnston 1996, Aronson \& Blake 2001, Clarke et al. 2004, Clarke 2008). A mixture of taxa with different biogeographic affinities composes the SO marine benthic fauna: (1) a 
relict autochthonous fauna; (2) a fauna derived from adjacent deep-water basins; (3) a fauna dispersing from South America along the Scotia Arc; and (4) a fauna which has spread in the opposite direction from Antarctica northwards along the Scotia Arc (Knox \& Lowry 1977, Clarke 2008). Several groups of marine invertebrates that are abundant and diverse in other adjacent regions are scarcely represented or even absent in the SO. Examples include key elements of gastropods, bivalves, decapods and fishes (Crame 1999, Aronson \& Blake 2001). However, other marine groups such as porifera, bryozoa, echinodermata, polychaeta, ascidians, pycnogoniids, amphipods and isopods are highly abundant and diverse, suggesting that major climatic and oceanographic changes in the region did not impede their evolutionary success (Clarke \& Crame 1989, 1992, Clarke \& Johnston 1996, Aronson \& Blake 2001, Linse et al. 2006, Rogers 2007, Aronson et al. 2008). In a recent revision of the biogeographical patterns of the marine benthic fauna in the Southern Ocean, Griffiths et al. (2009) stated that the regions in the SO differ depending upon the class of organisms being considered. According to their results, some general rules are possible, including high levels of endemism (around $50 \%$ ), a single Antarctic Province and a clear distinction between the sub-Antarctic islands influenced by South America and those of New Zealand.

High levels of faunal affinities are particularly clear between Antarctica and the southern tip of South America, commonly known as the Antarctic-Magellan connection (Arntz 1999, 2005, Brandt et al. 1999, Crame 1999, Arntz et al. 2005, Thatje et al. 2005, Rogers 2007, Aronson et al. 2008). The traditional interpretation for this affinity is that these regions were contiguous until the opening of the Drake Passage and were progressively separated by deep waters from the Eocene/Oligocene (Crame 1999). Marine invertebrates from different provinces of the SO such as Euphausia (Patarnello et al. 1996), Affrolittorina and Austrolittorina (Williams et al. 2003, Waters et al. 2007), and fishes (Clarke \& Johnston 1996, Waters et al. 2000) exhibit important levels of genetic divergence, supporting vicariance speciation by the plate tectonics hypothesis. Nevertheless, new molecular evidence in other groups of marine invertebrates, especially in those with high oceanic dispersive capacity, suggest more recent divergence processes than those expected under the vicariance hypothesis and provide evidence for the importance of longdistance dispersal in the distribution of the SO marine benthic fauna (Helmuth et al. 1994, O'Foighill et al. 1999, Coyer et al. 2001, Page \& Linse 2002, Donald et al. 2005, Gérard et al. 2008, Waters 2008, Fraser et al. 2009, 2010, Díaz et al. 2011). Moreover, recent observations of non-Antarctic anomuran and bachyuran zoea stages in King George, Antarctic Peninsula (Thatje \& Fuentes 2003) indicate that some groups can travel across the ACC (Tavares \& De Melo 2004, Clarke et al. 2005). Similarly, records of non-Antarctic lithoid crabs in deep water off the Antarctic continental slope suggests that these crabs may be returning to this region (Thatje \& Arntz 2004, Thatje 2005, Thatje et al. 2005). These findings highlight the permeability of the polar front in space and time, raising questions about how organisms got to Antarctica and how often these processes happened in the past. Thatje \& Fuentes (2003) suggest that larvae might cross the polar front using eddies or intrusions of Sub-Antarctic water masses through the ACC. Satellite imagery indicates that the ACC, far from being a continuous barrier, has a complex mesoscale structure including eddies over a wide range of scales. Eddies are important transport mechanisms across the ACC, where warmcore rings can transport sub-Antarctic plankton to Antarctica, and cold-core rings can carry Antarctic plankton to warmer waters of the north (Glorioso et al. 2005).

The main objective of this study is to evaluate if the ACC has constituted an effective oceanographic barrier for larval dispersal between two Provinces of the Southern Ocean to estimate since it has operated. For this purpose we selected species of three genera, all characterized by possessing a planktotrophic larval stage. In order to discount the possibility of a deep-sea connection after the opening of the Drake Passage, we included groups of organisms with narrow bathymetrical distribution that are restricted to the continental shelves of both provinces. We determined the levels of molecular divergence between congeneric species of broadcasters, marine invertebrates 
from Antarctic Peninsula and southern South America. First we compared Sterechinus neumayeri (Meissner, 1900), a regular echinoid with a circum-Antarctic distribution with S. agassizii (Mortensen, 1910) from the Argentinian continental shelf. Second, we compared the Antarctic limpet Nacella concinna (Strebel, 1908) with its Magellanic relative Nacella magellanica (Gmelin, 1791). Finally, we compared the Antarctic bivalve Yoldia eightsi (Jay, 1839) with the Magellanic species Yoldia woodwardi (Hanley, 1860). The information contained in their DNA sequences will permit us to estimate rhythms and trends in the biogeography of marine benthic near-shore organisms in this Region.

\section{METHODS}

We analyzed a partial fragment of the mitochondrial gene Cytochrome c Oxidase Subunit I (COI) in congeneric species of Sterechinus (945 bp, Díaz et al. 2011), Nacella (662 bp, González-Wevar et al. 2011a, 2011b) and Yoldia (688 bp) from the Antarctic Peninsula and the Magellanic Province. Specimens of the Antarctic limpet Nacella concinna were collected from five localities along the western Antarctic Peninsula (González-Wevar et al. 2011a) and N. magellanica was collected in three localities along its distribution in the Magellanic Province (González-Wevar et al. 2011b). Sterechinus neumayeri were collected from two localities of the western Antarctic Peninsula (Fildes and Covadonga Bay) and $S$. agassizi samples were collected from different localities on the Argentinean continental shelf, Magellanic Province (Díaz et al. 2011). Finally, we included in the analyses five individuals of Yoldia eightsi collected in Fildes Bay, King George Island, Antarctica and five specimens from Porvenir Bay, Magellan Strait. The COI gene was amplified in Yoldia using the universal primers described by Folmer et al. (1994). Amplicons were purified and sequenced in both directions by Macrogen (South Korea). Sequences were edited with Proseq 2.91 (Filatov 2002) and aligned with Clustal W (Thompson et al. 1992).

We estimated divergence times between Antarctic and Magellanic lineages considering the number of pairwise differences between species from the provinces and assuming a strict molecular clock hypothesis. Previous to assuming this hypothesis we performed a likelihood ratio test (Felsenstein 1981) using DAMBE (Xia \& Xie 2001). Divergence time estimations were made using specific mutational rates for each group. In the case of Nacella we used a substitution rate estimated for nacellid limpets (1.0\% per million year, GonzálezWevar unpublished data). In the case of Sterechinus, we selected two substitution rates $0.51 \%$ and $0.72 \%$ per million year, according to Lee et al. (2004) for Echinidae. For Yoldia we used a substitution rate of $0.95 \%$ per million year (Wares \& Cunningham 2001).

We constructed genealogical relationships in all three genera with haplotype networks using the Median-Joining algorithm in Network 4.6 (Röhl 2002, http://www.fluxus-engineering.com). This method allows simple reconstructions of phylogenies based on intraspecific genetic data such as mitochondrial DNA variation (Bandelt et al. 1999, Posada \& Crandall 2001).

We determined levels of genetic polymorphism in Nacella and Sterechinus species using standard diversity indices: number of haplotypes $(\mathrm{k})$, number of segregating sites (S), and haplotype diversity $(\mathrm{H})$ for each province using DnaSP 5.00.07 (Librado \& Rozas 2009). We also estimated average pairwise sequence differences $(\Pi)$ and nucleotide diversity $(\varpi)$. We performed mismatch distribution analyses in Nacella and Sterechinus species using pairwise distances as an assessment of population demographic histories. To determine whether the populations have undergone sudden population growth we compared the mismatch distribution of haplotype differences among haplotypes of Nacella and Sterechinus COI sequence data sets with expectations of a sudden expansion model (Rogers \& Harpending 1995). The goodness of fit between the observed and expected mismatch distributions was tested using a parametric bootstrap approach that uses the sum of squared deviations between observed and expected mismatch distributions as a test statistic, as implemented in Arlequin 2.0 (Schneider et al. 2000).

\section{RESULTS}

We detected major genetic discontinuities between Antarctic and Magellanic congeneric species of Sterechinus, Nacella and Yoldia. This was shown by the high levels of genetic divergence $(>7.0 \%$ ) between species from the two provinces. Sterechinus neumayeri (Antarctica) and S. agassizi (South America) exhibited $7.2 \%$ difference, with an average of 56 nucleotide differences between species (Fig. 1A). Similarly, N. concinna (Antarctica) and N. magellanica (Magellanic Province) had $7.7 \%$ difference, with an average of 51.4 nucleotide differences between species (Fig. 1B). Yoldia eighsi from Antarctica showed $7.0 \%$ difference with $Y$. woodwardi from southern South America and an average of 48.2 nucleotide differences between species (Fig. 1C). Divergence time estimations between species from the two provinces of the SO indicate that the analyzed congeneric species were separated by the following mutational times: 28 for Sterechinus, 26.2 for Nacella and 24.1 for Yoldia. Considering specific substitution rates, the separation of the three groups of benthic invertebrates occurred during the Pliocene (between 5.0 and $3.7 \mathrm{Ma}$ ). In the case of Sterechinus the last contact between $S$. neumayeri and $S$. agassizi occurred between 4.4 and $5.0 \mathrm{Ma}$, while the separation between the Antarctic limpet $N$. concinna from its Magellanic relative $N$. magellanica took place $\sim 3.7 \mathrm{Ma}$. Finally, the separation between 

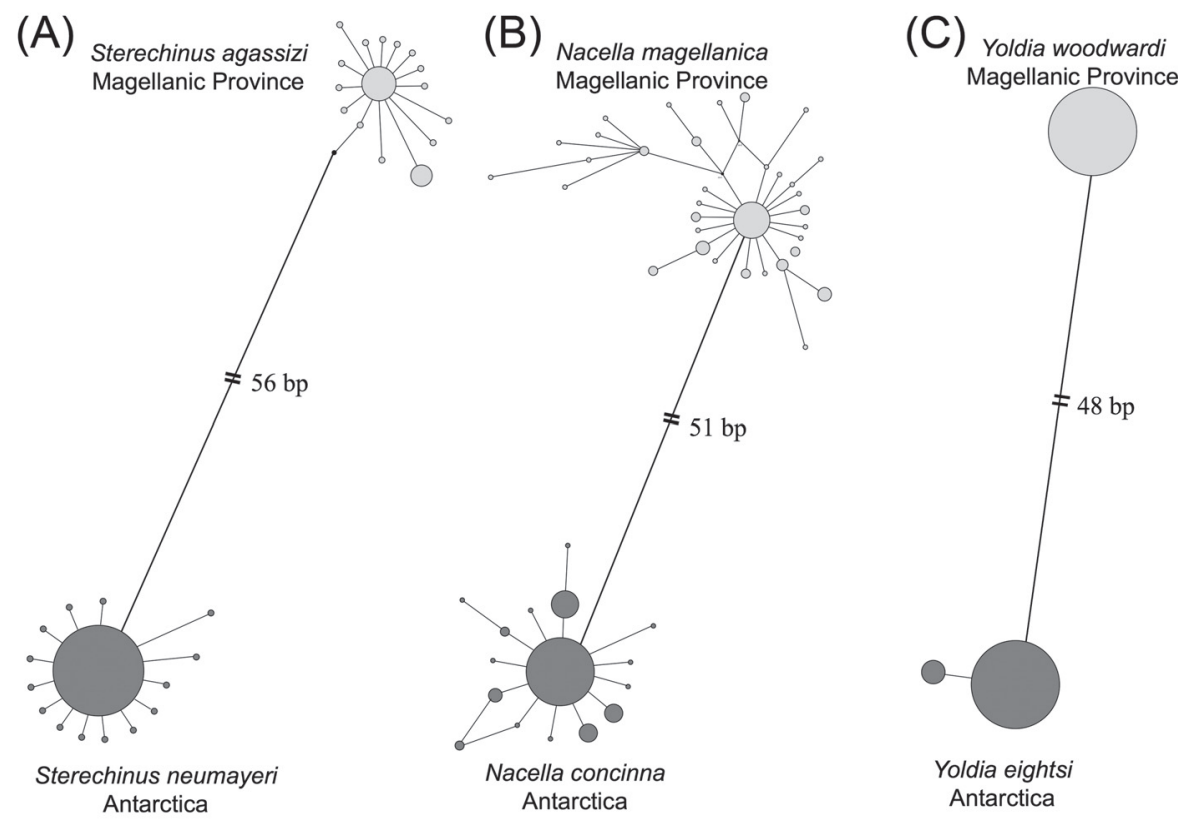

Fig. 1: Haplotype Networks constructed using COI sequences from Antarctic and Magellanic congeneric species of: A) Sterechinus $(\mathrm{n}=150), \mathrm{B})$ Nacella $(\mathrm{n}=191)$; C) Yoldia $(\mathrm{n}=10)$. Each haplotype is represented by a circle whose size is proportional to its frequency.

Red de haplotipos construidos usando secuencias COI en especies congenéricas de: A) Sterechinus $(\mathrm{n}=150)$, B) Nacella $(\mathrm{n}=$ 191); C) Yoldia $(\mathrm{n}=10)$. Cada haplotipo es representado por un círculo cuyo tamaño es proporcional a su frecuencia.

Yoldia eightsi from Antarctica and Y. woodwardi from southern South America occurred 3.9 Ma.

Haplotype networks showed clear differences between Antarctic and Magellanic species of Nacella and Sterechinus (Figs. $1 \mathrm{~A}$ and $1 \mathrm{~B})$. In general, haplotype networks of Magellanic species (S. agasizzi and $N$. magellanica) showed higher levels of diversity in terms of the number of haplotypes and the extension of the genealogy than their Antarctic relatives ( $S$. neumayeri and $N$. concinna). These results were further corroborated by the levels of genetic diversity detected in Antarctic and Magellanic species of Nacella and Sterechinus. In both genera, South American species exhibited higher levels of genetic diversity measured as haplotype numbers (k), polymorphic sites (S), and haplotype diversity (H). Similarly, the average number of pairwise difference (П) was six times greater in $S$. agassizi (1.88) from the Magellanic Province than in S. neumayeri (0.30) from Antarctica and almost three times greater in $N$. magellanica
(2.338) than in the Antarctic limpet $N$. concinna (0.850, Table 1$)$. We detected clear differences in the shape of the mismatch distributions between Antarctic and sub-Antarctic species of Nacella and Sterechinus that reflect differences in their demographic histories. For instance pairwise differences of Antarctic species $S$. neumayeri (Fig. 2A) and $N$. concinna (Fig. 2C) are characterized by L-shaped distributions, while $S$. agassizi (Fig. 2B) and N. magellanica (Fig. 2D) from southern South America showed unimodal and bimodal patterns of distribution, respectively, further supporting clear differences in trends and rhythms of the demographic changes between the provinces of the SO.

\section{DISCUSSION}

Well-supported results derived from molecular data can potentially reveal important information about biogeographical and phylogeographical patterns, systematic relationships, conservation issues and 
TABLE 1

Genetic diversity indices in species of Nacella and Sterechinus from the Antarctic Peninsula and southern South America. $\mathrm{n}=$ number of sampled individuals; $\mathrm{k}=$ number of haplotypes; $\mathrm{S}=$ polymorphic sites; $\mathrm{H}=$ haplotype diversity; $\Pi=$ average number of nucleotide differences; $\varpi=$ nucleotide diversity.

Índices de diversidad genética en especies de Nacella y Sterechinus de Península Antártica y el Sur de Sudamérica. $\mathrm{n}=$ número de individuos muestreados; $\mathrm{k}=$ número de haplotipos; $\mathrm{S}=$ sitios polimórficos; $\mathrm{H}=$ diversidad haplotípica; $\Pi=$ número promedio de diferencias de nucleótidos; $\varpi$ = diversidad nucleotídica.

\begin{tabular}{lcccccc}
\hline Species & $\mathrm{n}$ & $\mathrm{K}$ & $\mathrm{H}$ & $\mathrm{S}$ & $\Pi$ & $\varpi$ \\
\hline Sterechinus neumayeri (Antarctica) & 110 & 15 & 0.239 & 17 & 0.309 & 0.0003 \\
Sterechinus agassizi (Magellanic Province) & 40 & 16 & 0.768 & 21 & 1.885 & 0.0019 \\
Nacella concinna (Antarctica) & 161 & 15 & 0.630 & 18 & 0.850 & 0.0012 \\
Nacella magellanica (Magellanic Province) & 81 & 38 & 0.828 & 29 & 2.338 & 0.0035 \\
\hline
\end{tabular}

divergence time estimations. In this study, our molecular analyses established clear differences between congeneric species of Sterechinus, Nacella and Yoldia. For each genus, species from Antarctic Peninsula and Southern South America constitute distinct Evolutionary Significant Units that were separated several million years ago. Based on these results, the ACC appears as an old and efficient barrier for these genera. It is important to note that the separation of congeneric species in three genera belonging to echinoids, gastropods and bivalves occurred in a brief evolutionary time measured in terms of mutational steps (between 28 and 24.1). These results suggest that the installation of an effective barrier for faunal interchange between Antarctica and southern South America occurred almost at the same time among these broadcastspawning invertebrates. Considering lineagespecific substitution rates, divergence time estimations suggest that the separation of these groups occurred during the Pliocene between 3.7 and 5.0 Ma. According to these divergence time estimates, the separation between Antarctic and South American taxa started long after the physical separation of both continents, estimated between $41 \mathrm{Ma}$ (Livermore et al. 2005) and 23.9 Ma (Eagles \& Livermore 2002, Pfühl \& McCave 2005, Scher \& Martin 2006, Barker et al. 2007, Lyle et al. 2007). This separation seems to be more related to climatic and oceanographic processes during the end of the Miocene, including an increase of $\mathrm{d}_{18} \mathrm{O}$ values associated with polar cooling, major growth of ice sheets in eastern Antarctica and main changes in ocean circulation (Woodruff \& Savin 1989, Flower \& Kennett 1994, Shevenell et al. 2004, Mackensen 2004). In fact, during the late Miocene an intense pattern of thermal zonation in the oceans has been described. This event might be responsible for an intensification of the ACC resulting in the differentiation of Antarctic and Sub-Antarctic fauna (Crame 1999). It is important to note that the taxonomy of Yoldia is still unclear. According to Rabarts \& Whybrow (1979) Yoldia in the Magellanic Province includes two different species, $Y$. eightsi and $Y$. woodwardi, both distributed in the Falkland Islands and Tierra del Fuego. We considered the Magellanic specimens of Yoldia as Y. woodwardi because of the observed differences with $Y$. eightsi. However, Dell (1964), Villarroel \& Stuardo (1998) and Huber (pers. comm. 2011) synonymized Y. eightsi and $Y$. woodwardi. In spite of these uncertainties in the taxonomy of Yoldia, the genetic divergence between Antarctic and sub-Antarctic specimens of Yoldia indicate that they do not constitute the same Evolutionary Significant Unit and should be considered as separate entities.

Our estimated times of the split between Antarctic and Sub-Antarctic species of Sterechinus, Nacella and Yoldia are congruent with other molecular studies in different taxonomic groups. For example, the separation between Antarctic and Sub-Antarctic notothenioid fishes (Patagonotothen and Lepidonotothen) ranged from $9 \mathrm{Ma}$ (Bargelloni et al. 2000a) to 7.1-6.1 Ma (Stankovic et al. 2002). Divergence analyses of the Antarctic 


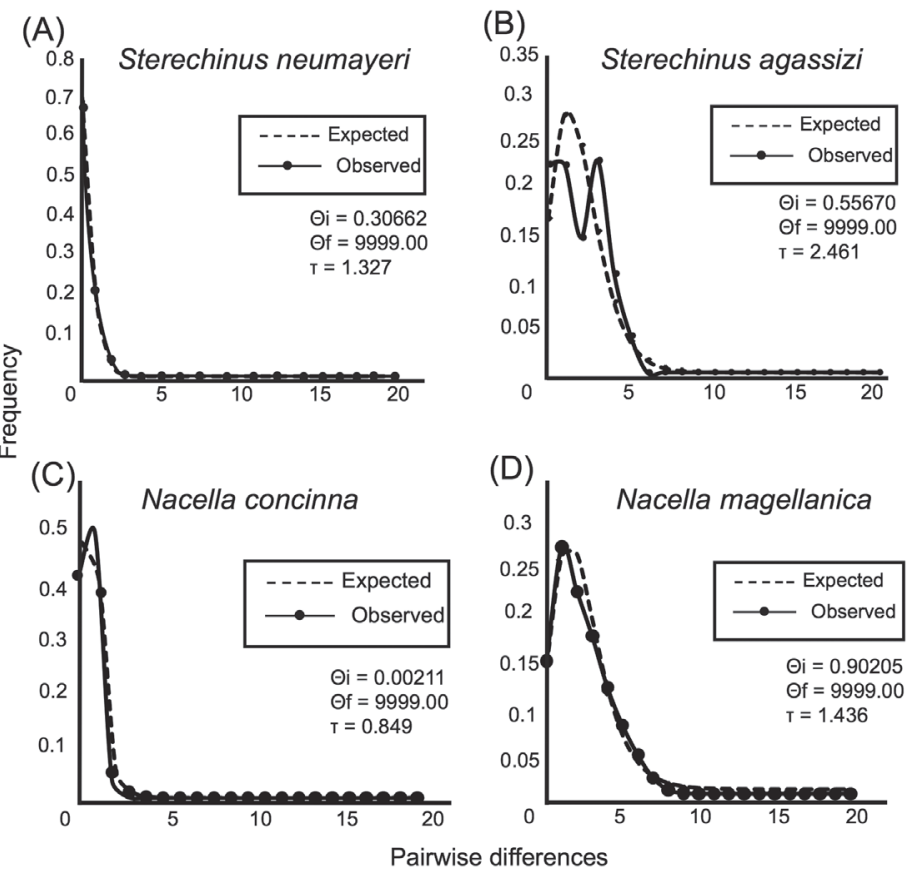

Fig. 2: Pairwise difference distribution for the Cytochrome c oxidase subunit I (COI) in Antarctic and Magellanic species of Nacella and Sterechinus. A) Sterechinus neumayeri; B) Sterechinus agassizi; C) Nacella concinna; D) Nacella magellanica . $\mathrm{x}$-axis = Pairwise differences and $\mathrm{y}$-axis = Frequency.

Distribución de diferencias pareadas para Citocromo c oxidase subunidad I (COI) en especies Antárticas y Subantárticas de Nacella y Sterechinus. A) Sterechinus neumayeri; B) Sterechinus agassizi; C) Nacella concinna; D) Nacella magellanica. eje $\mathrm{x}=$ Diferencias pareadas y eje $\mathrm{y}=$ Frecuencia.

bivalve Limatula ovalis and its Sub-Antarctic relative L. pygmaea suggest a separation between 8.03 and $5.79 \mathrm{Ma}$ (Page \& Linse 2002). The separation between two sister species of euphaisiids distributed north (E. valentini) and south (E. frigida) of the Antarctic Polar Front occurred $\sim 7.0 \mathrm{Ma}$ (Bargelloni et al. 2000b). Divergence time estimations between Antarctic and Sub-Antarctic individuals of the cryptic species of the crinoid Promachocrinus suggest a split between 3.75-4.24 Ma (Wilson et al. 2007). Thornhill et al. (2008), analyzing the levels of genetic differentiation in Antarctic and Sub-Antarctic populations of Parbolasia corrogatus, estimated that the separation of the groups occurred between 14.5-4.2 Ma. Hunter \& Halanych (2008) using a divergence rate for echinoderms (3.1-3.5 \%) estimated that the separation between Antarctic and Sub-Antarctic populations of the brittle star Astrotoma agassizii occurred at 1.4-1.6 Ma. Similarly, Janosik et al. (2011), using the same divergence rate, estimated that the separation between Odontaster penicilliatus (Sub-Antarctic) and O. pearsei (Antarctic) occurred $\sim 1.0 \mathrm{Ma}$. However, the levels of genetic differentiation between Antarctic and Sub-Antarctic populations of Astrotoma (6.8 $\%)$ are similar to those detected in congeneric species of Sterechinus (7.2 \%), Nacella (7.7 $\%)$ and Yoldia (7.0 \%). Similarly, genetic divergence estimations between Antarctic and Sub-Antarctic populations of the bivalve Lissarca notorcadensis (5.0-5.4, Linse et al. 2007) are also comparable to those estimated in this study. In summary, these studies between Antarctic and Sub-Antarctic invertebrate taxa indicate that, in spite of the substitution rate selected, the separation of marine benthic taxa of the regions occurred near the transition between Miocene and Pliocene and therefore long after the geographical separation of these provinces of the SO.

Climate change is one of the major forces driving population extinctions, particularly near the limit of a species' range (Hewitt 1996). 
Paleontological and palynological records have demonstrated that many species have undergone significant latitudinal shifts in response to the advances and retreats of Quaternary glacial ice sheets, and particularly to the recent Last Glacial Maximum (LGM) between 23.000-18.000 years ago (Webb \& Bartlein 1992, Hewitt 2000, 2004, Provan \& Bennett 2008). Especially at higher latitudes, ice sheet advances and retreats, surrounding permafrost, lower global temperature, sea level variations, and reduced water availability caused major changes in the distribution of species (Bennett 1997, Huybrechts 2002). During the LGM, many species went extinct over large parts of their range, some dispersed to new template habitats, others survived in lower latitude refugia and subsequently expanded their range through interglacial recolonization (Hewitt 2000, 2004). Relatively little is known about the biotic effects of recent glaciations in the Southern Hemisphere, where ice-sensitive benthic biota of Antarctic and sub-Antarctic regions would have endured significant processes of extinction and recolonization as sea ice covered the SO (Fraser et al. 2009). In fact, contemporary ice scouring is known to purge much of the shallow water benthos in Antarctica (Gutt 2001, Barnes \& Conlan 2007), and the coastlines within the LGM sea ice limits (Fraser et al. 2009). Genetic comparisons of standard diversity indices in Antarctic and Sub-Antarctic species of Nacella and Sterechinus suggest a more pronounced effect of the Quaternary glacial cycles in Antarctica than in southern South America. In general, even when we included at least twice the number of individuals of the Antarctic species $N$. concinna and $S$. neumayeri, they exhibited lower levels of genetic diversity $(k$, $\mathrm{S}, \mathrm{H}, \Pi$ and $\varpi)$ in comparison to the Magellanic species ( $N$. magellanica and $S$. agassizi). These results could reflect the dramatic effect of the Quaternary glacial periods on population sizes, especially for species with narrow bathymetric ranges. In this respect, the results obtained in $N$. concinna and $S$. neumayeri contrast with other studies in Antarctic invertebrates that showed higher levels of genetic diversity (Mahon et al. 2008, Thornhill et al. 2008, Krabbe et al. 2009, Wilson et al. 2009, GoodallCopestake et al. 2010, Arango et al. 2011). However, most of these species have large bathymetrical ranges that could have helped them to prevent the drastic demographic impact during Quaternary glacial cycles (Brey \& Clarke 1993, Brey et al. 1996). During glacial maxima the ice edge advanced across all land and the continental shelf, bulldozing the surviving fauna to the deep continental margin (Grobe \& Mackensen 1992, Barnes \& Conlan 2007). Shallower continental shelf and terrestrial environments thus had to be repeatedly re-colonized during interglacial periods of ice retreat. Considering the bathymetrical range of Nacella and Sterechinus, the extension of glacial continental ice-sheets over main part of the Antarctic Peninsula should have drastically reduced their habitats to isolated ice-free glacial areas (Poulin et al. 2002, Thatje et al. 2005). However, there is still no evidence of such ice-free marine areas in Antarctic Peninsula (Barnes \& Conlan 2007). Another possibility includes range contraction of both species to ice-free areas in the northern extreme of their distributions to Antarctic islands of the Scotia Arc such as the South Georgia and Signy Islands. Then during interglacial periods both species could have re-colonized the Antarctic Peninsula through larval dispersal. According to this, founder effects could constitute a plausible explanation for the low genetic diversity detected in these species. This scenario is also supported by star-like genealogies with very short branches (Figs. 1A and 1B), and marked L-shaped distributions of pairwise differences in Antarctic Nacella and Sterechinus (Figs. 2A and $2 \mathrm{C}$ ).

Finally, the present study gives new insight into the patterns of genetic differentiation between the Antarctic Peninsula and southern South America marine near-shore invertebrates with high dispersive capacity. According to our results, in organisms with free-living larvae such as Sterechinus, Nacella and Yoldia, the divergence between Antarctic and SubAntarctic lineages was initiated long after the physical separation of Antarctica and South America. After the Miocene-Pliocene transition the intensification of the ACC constituted an efficient barrier for gene flow across these Provinces. None of the analyzed genera exhibited evidence for recurrent gene flow across the APF for several Ma. In this respect, the recent discovery of decapod larvae 
in Antarctic Peninsula probably represents exceptional events related to present rapid climatic changes or to an increase in marine human traffic (scientific and tourism) between South America and the Antarctic Peninsula. Moreover, genetic diversity analyses indicate that Antarctic and Sub-Antarctic taxa have been differentially impacted by glacial periods, and this situation was more evident in Antarctic species with narrow bathymetrical ranges.

ACKNOWLEDGEMENTS: This study was supported by the following institutions and grants: Thesis projects INACH B_01_07 and INACH Office project G_04-11, Conicyt Ph.D. D-21060218 and IDEAWILD to C.G-W; Fondecyt post-doctorate 3100139 to K.G; INACH D_05-09 and Conicyt Ph.D. D_21-08 to A.D; FIP Project 200544 and Research Programs PR-F2-01CNR-10 and 0273, Universidad de Magallanes (J.I.C.). At the same time, this research was supported by the Projects P05-002 ICM and PFB 023 (Institute of Ecology and Biodiversity IEB, Universidad de Chile), INACH 02-02, INACH 13-05, and ECOS C06B02 to E.P. Thanks are also due to international program as CAML, EBA-SCAR and PROSUL-Brazil for encouraging and supporting Antarctic research in Evolution.

\section{LITERATURE CITED}

ALJNABI SM \& I MARTÍNEZ (1997) Universal and rapid salt-extraction of high quality genomic DNA for PCR-based techniques. Nucleic Acids Research 25: 4692-4693.

ARANGO CP, A SOLER-MEMBRIVES \& KJ MILLER (2011) Genetic differentiation in the circumAntarctic sea spider Nymphon australe (Pycnogonida; Nymphonidae) Deep Sea Research II: Topical Studies in Oceanography 58: 212-219.

ARNTZ WE (1999) Magellan-Antarctic: Ecosystems that drifted apart: Summary Review. Scientia Marina 63: 503-511.

ARNTZ WE (2005) The Magellan-Antarctic connection: Links and frontiers at southern high latitudes. Scientia Marina 69: 359-365.

ARNTZ WE, S THATJE, D GERDES, J-M GILI, J GUTT et al. (2005) The Antarctic-Magellan connection: Macrobenthos ecology on the shelf and upper slope, a progress report. Scientia Marina 69: 237269.

ARONSON RB \& DB BLAKE (2001) Global climate change and the origin of modern benthic communities in Antarctica. American Zoologist 41: $27-39$.

ARONSON RB, THATJE S, A CLARKE, LS PECK, BLAKE DB, CD WILGA \& BA SIEBEL (2007) Climate change and invasibility of the Antarctic benthos. Annual Review of Ecology, Evolution, and Systematics 38: 129-154.

BANDELT H-J, P FORSTER \& A RÖHL (1999) Medianjoining networks for inferring intraspecific phylogenies. Molecular Biology and Evolution 16: 37-48.

BARGELLONI L, S MARCATO, L ZANE \& T PATARNELLO (2000a) Mitochondrial phylogeny of Notothenioids: A molecular approach to Antarctic fish evolution and biogeography. Systematic Biology 49: 114-129.

BARGELLONI L, L ZANE, N DEROME, N LEICONTRE \& T PATARNELLO (2000b) Molecular zoogeography of Antarctic euphausiids and notothenioids: From species phylogenies to intraspecific patterns of genetic variation. Antarctic Science 12: 259-268.

BARKER PF \& E THOMAS (2004) Origin, signature and paleoclimatic influence of the Antarctic Circumpolar Current. Earth-Science Reviews 66: 143-162.

BARKER PF, GM FILIPELLI, F FLORINDO, EE MARTIN \& HD SCHER (2007) Onset and role of the Antarctic Circumpolar Current. Deep Sea Research II. Topical Studies in Oceanography 54: 2388-2398.

BARNES DKA \& KE CONLAN (2007) Disturbance, colonization and development of Antarctic benthic communities. Philosophical Transactions of the Royal Society B 362: 11-38.

BENNET KD (1997) Evolution and ecology: The pace of life. Cambridge University Press, Cambridge.

BEU AG, M GRIFFIN \& RA MAXWELL (1997) Opening of Drake Passage gateway and late Miocene to Pleistocene cooling reflected in Southern Ocean molluscan dispersal: Evidence from New Zealand and Argentina. Tectonophysics 281: 83-97.

BRANDT A, K LINSE \& U MÜHLENHARDT-SIEGEL (1999) Biogeography of Crustacea and Mollusca of the Subantarctic and Antarctic regions. Scientia Marina 63: 383-389.

BREY T \& A CLARKE (1993) Population dynamics of marine benthic invertebrates in Antarctic and subantarctic environments: Are there unique adaptations? Antarctic Science 5: 253-266.

BREY T, C DAHM, M GORNY, M KLAGE, M STILLER \& WE ARNTZ (1996) Do Antarctic marine benthic invertebrates show an extended level of eurybathy? Antarctic Science 8: 3-6.

CLARKE A \& A CRAME (1989) The origin of the Southern Ocean marine fauna. In: Crame A (ed) Origins and evolution of the Antarctic Biota: 253268. Geological Society Special Publication 47, London.

CLARKE A \& A CRAME (1992) The Southern Ocean benthic fauna and climate change: An historical perspective. Philosophical Transactions of the Royal Society B 308: 299-309.

CLARKE A \& IA JOHNSTON (1996) Evolution and adaptative radiation of Antarctic fishes. Trends in Ecology and Evolution 11: 211-218.

CLARKE A, RB ARONSON, JA CRAME, J-M GILI \& DB BLAKE (2004) Evolution and diversity of the benthic fauna of the Southern Ocean continental shelf. Antarctic Science 16: 559-568.

CLARKE A, DKA BARNES \& DA HODGSON (2005) How isolates is Antarctica? Trends in Ecology and Evolution 20: 1-3.

CLARKE A (2008) Antarctic marine benthic diversity: Patterns and processes. Journal of Experimental Marine Biology and Ecology 366: 48-55.

COYER JA, GJ SMITH \& RA ANDERSON (2001) Evolution of Macrocystis spp. (Phaophyceae) as determined by ITS1 and ITS2 sequences. Journal of Phycology 37: 574-585.

CRAME JA (1999) An evolutionary perspective on marine faunal connection between southernmost 
South America and Antarctica. Scientia Marina 63: $1-14$

DELL RK (1964) Antarctic and Subantarctic Mollusca: Amphineura. Scaphopoda and Bivalvia. Discovery Reports (Cambridge University Press, UK) 33: 93-250.

DÍAZ A, J-P FÉRAL, B DAVID, T SAUCÈDE \& E POULIN (2011) Evolutionary pathways among shallow and deep sea echinoids of the genus Sterechinus in the Southern Ocean. Deep Sea Research II: Topical Studies in Oceanography 58: 205-211.

DONALD KM, M KENNEDY \& HG SPENCER (2005) Cladogenesis as the result of long-distance rafting events in South Pacific topshells (Gastropoda, Trochidae). Evolution 59: 1701-1711.

EAGLES G \& RA LIVERMORE (2002) Opening history of Powell Basin, Antarctic Peninsula. Marine Geology 185: 195-205.

EXCOFFIER L, G LAVAL \& S SCHNEIDER (2005) Arlequin ver. 3.0: An integrated software package for population genetics data analysis. Evolution Bioinformatics Online 1: 47-50.

FELSENSTEIN J (1981) Evolutionary trees from DNA sequences: A maximum likelihood approach. Journal of Molecular Evolution 17: 368-376.

FILATOV DA (2002) PROSEQ: A software for preparation and evolutionary analysis of DNA sequence data sets. Molecular Ecology Notes 2: 621-624.

FLOWER BP \& JP KENNETT (1994) The middle Miocene climatic transition: East Antarctic ice sheet development, deep ocean circulation and global carbon cycling. Palaeogeography, Palaeoclimatology, Palaeoecology 108: 537-555.

FOLMER M, M BLACK, W HOEH, R LUTZ \& R VRIJENHOEK (1994) DNA primers for amplification of mitochondrial cytochrome c oxidase subunit I from diverse metazoan invertebrates. Molecular Marine Biology and Biotechnology 3: 294-299.

FRASER CI, R NIKULA, H SPENCER \& JM WATERS (2009) Kelp genes reveal effects of Subantarctic Sea ice during the last glacial maximum. Proceedings of the National Academy of Sciences USA 106: 3249-3253.

FRASER CI, M THIEL, HG SPENCER \& JM WATERS (2010) Contemporary habitat discontinuity and historic glacial drive genetic divergence in Chilean kelp. BMC Evolutionary Biology 10: 203: $1-12$

GÉRARD K, N BIERNE, P BORSA, A CHENUIL \& J-P FÉRAL (2008) Pleistocene separation of mitochondrial lineages of Mytilus spp. Mussels from northern and southern hemisphere and strong genetic differentiation among southern populations. Molecular Phylogenetics and Evolution 49: 84-91.

GERSONDE R, X CROSTA \& A ARMAND (2005) Seasurface temperature and sea ice distribution of the Southern Ocean at the EPILOG Last Glacial Maximum-a circum-Antarctic view based on siliceous microfossil records. Quaternary Science Reviews 24: 869-896.

GLORIOSO PD, AR PIOLA \& RR LEBEN (2005) Mesoscale eddies in the Subantarctic Front -Southwest Atlantic. Scientia Marina 69: 1-15.

GONZÁLEZ-WEVAR CA, T NAKANO, JI CAÑETE \& E POULIN (2010) Molecular phylogeny and historical biogeography of Nacella
(Patellogastropoda: Nacellidae) in the Southern Ocean. Molecular Phylogenetics and Evolution 56: 115-124.

GONZÁLEZ-WEVAR CA, B DAVID \& E POULIN (2011a) Phylogeography and demographic inference in Nacella (Patinigera) concinna (Strebel, 1908) in the western Antarctic Peninsula. Deep Sea Research II: Topical Studies in Oceanography 58: 220-229.

GONZÁLEZ-WEVAR CA, NAKANO T, JI CAÑETE \& E POULIN (2011b) Concerted genetic, morphological and ecological diversification in Nacella limpets in the Magellanic Province. Molecular Ecology 20: 1936-1951.

GOODALL WP, S PEREZ-ESPONA, MS CLARK, EJ MURPHY, PJ SEEAR \& GA TARLING (2010) Swarms of diversity at the gene cox1 in Antarctic krill. Heredity 104: 513-518.

GRIFFITHS HJ, DKA BARNES \& K LINSE (2009) Towards a generalized biogeography of the Southern Ocean benthos. Journal of Biogeography 36: 162-177.

GROBE H \& A MACKENSEN (1992) Late Quaternary climatic cycles as recorded in sediments from the Antarctic continental margin. Antarctic Research Series 56: 349-376.

GUTT J (2001) On the direct impact of ice on marine communities, a review. Polar Biology 24: 553-564.

HASSOLD NJC, DK REA, BA VAN DER PLUIJIN \& JM PARÉS (2009) A physical record of the Antarctic Circumpolar Current: Late Miocene to recent slowing of abyssal circulation. Palaeogeography Palaeoclimatology Palaeoecology 275: 28-36.

HELMUTH B, RR VEIT \& R HOLBERTON (1994) Longdistance dispersal of a subantarctic brooding bivalve (Gaimardia trapesina) by kelp-rafting. Marine Biology 120: 421-426.

HEWITT GM (1996) Some genetic consequences of ice ages, and their role in divergence and speciation. Biological Journal of the Linnean Society 58: 247276.

HEWITT GM (2000) The genetic legacy of Quaternary ice ages. Nature 405: 907-913.

HEWITT GM (2004) Genetic consequences of climatic oscillations in the Quaternary. Philosophical Transactions of the Royal Society B 359: 183-195.

HUNTER RL \& KM HALANYCH (2008) Evaluating connectivity in the brooding brittle star Astrotoma agassizzi across the Drake Passage in the Southern Ocean. Journal of Heredity 99: 137-148.

HUYBRECHTS P (2002) Sea-level changes at the LGM from ice-dynamics reconstructions of the Greenland and Antarctic ice sheets during the last glacial cycles. Quaternary Science Reviews 21: 203-231.

JANOSIK AM, AR MAHON \& KM HALANYCH (2011) Evolutionary history of the Southern Ocean Odontaster sea star species (Odontasteridae; Asteroidea). Polar Biology 24: 575-586.

KENNETT JP (1980) Paleoceanography and biogeographic evolution of the Southern Ocean during the Cenozoic, and Cenozoic microfossil datums. Palaeogeography, Palaeoclimatology, Palaeoecology 31: 123-152.

KNOX GA (1980) Plate tectonics and the evolution of intertidal and shallow-water benthic biotic distribution patterns of the Southwest Pacific. Palaeogeography Palaeoclimatol. Palaeoecology 31: 267-297. 
KNOX GA (2007) Biology of the Southern Ocean. Second edition. CRC Press, Taylor \& Francis Group, Boca Raton, FL.

KNOX GA \& JK LOWRY JK (1977) A comparison between the benthos of the Southern Ocean and the North Polar Ocean with special reference to the Amphipoda and the Polychaeta. In: Dunbar MJ (ed) Polar oceans: 423-462. Arctic Institute of North America, Calgary.

KRABBE K, F LEESE, C MAYER, R TOLLRIAN \& C HELD (2009) Cryptic mitochondrial lineages in the widespread pycnogonid Colossendeis megalonyx Hoek, 1881 from Antarctic and Subantarctic waters. Polar Biology 33: 282-291.

LAWVER LA \& LM GAHAGAN (2003) Evolution of Cenozoic seaways in the circum-Antarctic region. Palaeogeography, Palaeoclimatology, Palaeoecology 198: 11-37.

LEE Y-H, M SONG, S LEE, R LEÓN, S GODOY \& JI CAÑETE (2004) Molecular phylogeny and divergence time of the Antarctic sea urchin (Sterechinus neumayeri) in relation to the South American sea urchins. Antarctic Science 16: 29-36.

LIBRADO P \& J ROZAS (2009) DnaSP v5: A software for comprehensive analysis of DNA polymorphism data. Bioinformatics 25: 1451-1452.

LINSE K, HJ GRIFFITHS, DKA BARNES \& A CLARKE (2006) Biodiversity and biogeography of Antarctic and sub-Antarctic mollusca. Deep Sea Research II: Topical Studies in Oceanography 53: 985-1008.

LINSE K, T COPE, AN LÖRZ \& C SANDS (2007) Is the Scotia Sea a centre of Antarctic marine diversification? Some evidence of cryptic speciation in the circum-Antarctic bivalve Lissarca notocardensis (Arcoidea: Philobryidae). Polar Biology 30: 1059-1068.

LIVERMORE R, A NANKIVELL, G EAGLES \& P MORRIS (2005) Paleogene opening of Drake Passage. Earth and Planetary Science Letters 236: 459-470.

LYLE M, S GIBBS, TC MOORE \& DK REA (2007) Late Oligocene initiation of the Antarctic Circumpolar Current: Evidence from the South Pacific. Geology 35: 691-694.

MACKENSEN A (2004) Changing Southern Ocean palaeocirculation and effect on global climate. Antarctic Science 16: 369-384.

MAHON AR, CP ARANGO \& KM HALANYCH (2008) Genetic diversity of Nymphon (Arthropoda: Pignogonida: Nymphonidae) along the Antarctic Peninsula with focus on Nymphon australe Hodgson 1902. Marine Biology 155: 315-323.

Ó FOIGHILL D, BA MARSHALL, TJ HILLBISH \& MA PINO (1999) Trans-Pacific range extension by rafting inferred for the flat oyster Ostrea chilensis. Biological Bulletin 196: 122-126.

ORSI AH, T WHITWORTH III \& WD NOWLIN JR (1995) On the meridional extent and fronts of the Antarctic Circumpolar Current. Deep Sea Research I: Oceanographic Research Papers 42: 641-673.

PAGE TJ \& K LINSE (2002) More evidence of speciation and dispersal across the Antarctic Polar Front through molecular systematics of Southern Ocean Limatula (Bivalvia: Limidae). Polar Biology 25: 818-826.

PATARNELLO T, L BARGELLONI, V VAROTTO \& B BATTAGLIA (1996) Krill evolution and the Antarctic Ocean currents: Evidence of vicariant speciation as inferred by molecular data. Marine Biology 126: 603-608.

PFÜHL HA \& NI McCAVE (2005) Evidence for late Oligocene establishment of the Antarctic Circumpolar Current. Earth and Planetary Science Letters 235: 715-728.

POSADA D \& KA CRANDALL (2001) Intraspecific phylogenetics: Trees grafting into networks. Trends in Ecology and Evolution 16: 37-45.

POULIN E, A PALMA \& J-P FÉRAL (2002) Evolutionary versus ecological success in Antarctic benthic invertebrates. Trends in Ecology and Evolution 17: 218-222.

PROVAN J \& KD BENNETT (2008) Phylogeographic insights into cryptic glacial refugia. Trends in Ecology and Evolution 23: 564-571.

PUDSEY CJ \& JA HOWE (1998) Quaternary history of the Antarctic Circumpolar Current: Evidence from the Scotia Sea. Marine Geology 148: 83-112.

RABARTS IW \& S WHYBROW (1979) A revision of the Antarctic and Subantarctic members of the genus Yoldia Moller 1842 (Bivalvia: Nuculanidae). Journal of Natural History 13: 161-183.

RINTOUL SR, C HUGHES \& D OLBERS (2001) The Antarctic Circumpolar Current System. In: Siedler G, J Church \& J Gould (eds) Ocean circulation and climate: 271-302. New York Academic Press, New York.

ROGERS AR \& HARPENDING (1992) Population growth makes waves in the distribution of pairwise genetic differences. Molecular Biology and Evolution 9: 552-569.

ROGERS AD (2007) Evolution and biodiversity of Antarctic organisms: A molecular perspective. Philosophical Transactions of the Royal Society B 362: 2191-2214

RÖHL A (2002) NETWORK software. URL: http://www. fluxus-engineering.com.

SCHER HD \& EE MARTIN (2006) Timing and climatic consequences of the opening of Drake Passage. Science 312: 428-430.

SCHNEIDER S \& L EXCOFFIER (1999) Estimation of past demographic parameters from the distribution of pairwise differences when the mutation rates vary among sites. Application to human mitochondrial DNA. Genetics 152: 10791089.

SHAW PW, AI ARKHIPKIN \& H AL-KHAIRULLA (2004) Genetic structuring of Patagonia toothfish populations in the Southwest Atlantic Ocean: The effect on the Antarctic Polar Front and deep-water troughs as barriers to genetic distance. Molecular Ecology 13: 3293-3303.

SHEVENELL AE, JP KENNETT \& DW LEA (2004) Middle Miocene Southern Ocean cooling and Antarctic cryosphere expansion. Science 305: 1766-1770.

STANKOVIC A, K SPALIK, E KAMLER, P BORSUK \& P WEGLENSKI (2002) Recent origin of subAntarctic notothenioids. Polar Biology 25: 203-205.

STICKLEY CE, H BRINKHUIS, SA SCHELLENBERG, A SLUIJS, U RÖHL et al (2004) Timing and nature of the deepening of the Tasmanian Gateway. Paleoceanography 19: 1-18.

TAVARES M \& GAS DE MELO (2004) Discovery of the first known benthic invasive species in the Southern Ocean: The North Atlantic spider crab Hyas araneus found in the Antarctic Peninsula. Antarctic Science 16: 129-131. 
THATJE S (2005) The future fate of the Antarctic marine biota? Trends in Ecology and Evolution 20: 418419.

THATJE S \& V FUENTES (2003) First record of anomuran and brachyuran larvae (Crustacea: Decapoda) from Antarctic waters. Polar Biology 26: 279-282.

THATJE S \& WE ARNTZ (2004) Antarctic reptant decapods: More than a myth? Polar Biology 27: 195-201.

THATJE S, K ANGER, JA CALCAGNO, GA LOVRICH, H-O PÖRTNER \& WE ARNTZ (2005) Challenging the cold: Crabs reconquer the Antarctic. Ecology 86: 619-625.

THOMPSON JD, DG HIGGINS \& TJ GIBSON (1992) Clustal W: Improving the sensitivity of progressive multiple sequence alignment through sequence weighting, position specific gap penalties, and weight matrix choice. Nucleic Acids Research 22: 4673-4680.

THORNHILL DJ, AR MAHON, JL NORENBURG \& KM HALANYCH (2008) Open-ocean barriers to dispersal: A test case with the Antarctic Polar Front and the ribbon worm Parbolasia corrugatus (Nemertea: Lineidae). Molecular Ecology 17: 5104-5117.

THORPE SA, K HEYWOOD, D STEVENS \& MA BRANDON (2004) Tracking passive drifters in a high resolution ocean model: Implications for interannual variability of larvar krill transport to South Georgia. Deep Sea Research I: Oceanographic Research Papers 51: 909-920.

TORSVIK TH, C GAINA \& TF REDFIELD (2008) Antarctica and global paleogeography: From Rodinia, through Gondwanaland and Pangea, to the birth of the Southern Ocean and the opening of Gateways. In: Cooper AKP, J Barret, H Storey, E Stump \& W Wise (eds) Antarctica: A keystone in a changing world: 125-141. Proceedings of the $10^{\text {th }}$ International Symposium on Antarctic Earth Science. The National Academic Press, Washington, DC.

VILLARROEL M \& J STUARDO (1998) Protobranchia (Mollusca: Bivalvia) chilenos recientes y algunos fósiles. Malacologia 40: 113-229.

WARES JP \& CW CUNNINGHAM (2001) Phylogeography and historical ecology of the North Atlantic. Evolution 55: 2455-2469.

WATERS JM, LH DIJKSTRA \& GP WALLIS (2000) Biogeography of a southern hemisphere

Editorial responsibility: Álvaro T. Palma

Received November 18, 2011; accepted November 29, 2012 freshwater fish: How important is marine dispersal? Molecular Ecology 9: 1815-1821.

WATERS JM, GA McCULLOCH \& JA EASTON (2007) Marine biogeographical structure in two highly dispersive gastropods: Implications for transTasman dispersal. Journal of Biogeography 34: 678-687.

WATERS JM (2008) Driven by the West Wind Drift? A synthesis of southern temperate marine biogeography, with new directions for dispersalism. Journal of Biogeography 35: 1-11.

WEBB T \& PJ BARTLEIN (1992) Global changes during the last 3 million years: Climatic controls and biotic response. Annual Review of Ecology and Systematics 23: 141-173.

WILLIAMS JW, RL SUMMERS \& T WEBB III (1998) Applying plant functional types to construct biome maps from Eastern North American pollen data: Comparisons with model results. Quaternary Science Reviews 17: 607-627.

WILLIAMS ST, DG REID \& DJT LITTLEWOOD (2003) A molecular phylogeny of the Littorininae (Gastropoda: Littorinidae): Unequal evolutionary rates, morphological parallelism, and biogeography of the Southern Ocean. Molecular Phylogenetics and Evolution 28: 60-86.

WILSON NG, RL HUNTER, SJ LOCKHART \& KM HALANYCH (2007) Multiple lineages and absence of panmixia in the "circumpolar" crinoid Promachocrinus kerguelenensis from the Atlantic sector of Antarctica. Marine Biology 152: 895-904.

WILSON NG, M SCHRÖLD \& KM HALANYCH (2009) Ocean barriers and glaciation: Evidence for explosive radiation of mitochondrial lineages in the Antarctic sea slug Doris kerguelenensis (Mollusca, Nudibranchia). Molecular Ecology 18: 965-984.

WOODRUFF F \& SM SAVIN (1989) Miocene deepwater oceanography. Palaeoceanography 4: 87-140.

XIA X \& Z XIE (2001) DAMBE: Data analysis in molecular biology and evolution. Journal of Heredity 92: 371-373.

ZACHOS J, M PAGANI, L SLOAN, E THOMAS \& K BILLUPS (2001) Trends, rhythms, and aberrations on global climate $65 \mathrm{Ma}$ to present. Science 292: 686-693.

ZWALLY HJ, JC COMISO, CL PARKINSON \& $\mathrm{P}$ GLOERSEN (2002) Variability of Antarctic sea ice 1979-1998. Journal of Geophysical Resources 107: 3041-3059. 